\title{
VARIABEL YANG MEMPREDIKSI INTENTION TO USE BRAND E- PAYMENT DI JAKARTA
}

\author{
Willi Nathanael Febrian', Keni Keni²* \\ ${ }^{1}$ Program Studi Manajemen, Fakultas Ekonomi dan Bisnis, Universitas Tarumanagara, Jakarta \\ Email: willi.115160098@stu.untar.ac.id \\ ${ }^{2}$ Program Studi Manajemen, Fakultas Ekonomi dan Bisnis, Universitas Tarumanagara, Jakarta \\ Email: keni@fe.untar.ac.id \\ *Penulis Korespondensi
}

Masuk : 04-02-2021, revisi: 10-02-2021, diterima untuk diterbitkan :02-03-2021

\begin{abstract}
ABSTRAK
Penelitian ini bertujuan untuk mengkaji mengenai prediksi trust, perceived usefulness, dan perceived ease of use terhadap intention to use e-payment di Jakarta. Unified Theory of Acceptance dan Use of Technology (UTAUT) menjadi dasar dari penelitian ini, dimana teori tersebut menggambarkan bahwa terdapat hubungan antara penerimaan produk dan kepercayaan pengguna yang kemudian menjadi nilai yang penting bagi perusahaan $e$ payment. Penelitian ini merupakan penelitian deskriptif dengan pendekatan cross-sectional design. Pengumpulan sampel dilakukan dengan metode non-probability sampling dengan teknik convenience sampling. Data yang dikumpulkan dan kemudian dianalisis untuk menjawab hipotesis penelitan sebanyak 170 responden yang sudah pernah menggunakan e-payment untuk melakukan transaksi. Hasil penelitian ini menunjukkan bahwa trust dan perceived usefulness dapat memprediksi intention to use secara positif dan siginfikan, sedangkan perceived ease of use tidak dapat digunakan untuk memprediksi intention to use secara signifikan.
\end{abstract}

Kata Kunci: Kepercayaan, Persepsi Kemanfaatan, Persepsi Kemudahaan, Niat menggunakan

\section{ABSTRACT}

This study aims to examine the predictions of trust, perceived usefulness, and perceived ease of use on the intention to use e-payment in Jakarta. The Unified Theory of Acceptance and Use of Technology (UTAUT) is the basis of this research, whereas the theory illustrates that there is a relationship between product acceptance and user trust which then becomes an important value for e-payment companies. This research is a descriptive study with a crosssectional design approach. The sample was collected using a non-probability sampling method with a convenience sampling technique. Data were collected and then analyzed to answer the research hypothesis as many as 170 respondents who had used e-payments to make transactions. The results of this study indicate that trust and perceived usefulness can predict intention to use positively and significantly, while perceived ease of use cannot be used to predict intention to use significantly.

Keywords: Trust, Perceived Usefulness, Perceived Ease of Use, Intention to Use

\section{PENDAHULUAN}

\section{Latar belakang}

Pesatnya perkembangan teknologi informasi terjadi seiring dengan perkembangan media komunikasi, seperti yang terjadi pada perkembangan penggunaan internet yang dalam beberapa tahun terakhir sudah menjadi bagian kehidupan masyarakat. Pertumbuhan penggunaan internet tersebut kemudian menjadi peluang untuk e-commerce, dimana pelaku bisnis memanfaatkan peluang tersebut sebagai sebuah strategi untuk melakukan pemasaran secara online tanpa dibatasi oleh waktu dan jarak. Dalam melakukan jual beli atau pun bisnis secara online ada juga pembayaran secara online. Salah satu keuntungan e-payment adalah adanya promo-promo menarik yang diberikan oleh setiap pengelola aplikasi. Disamping itu, aplikasi e-payment lebih terjamin dalam hal penyimpanan uang karena tersimpan di aplikasi. 
Menurut Davis et al. (1989), intention to use sebagai suatu elemen penting dalam mengikat dan menarik konsumen untuk menggunakan suatu produk. Lebih lanjut, Davis (1989) melalui penelitiannya menjelaskan bahwa intention to use adalah kecenderungan pada perilaku konsumen untuk terus menggunakan produk yang diberikan oleh perusahaan. Perilaku konsumen dalam memutuskan menggunakan e-payment ditentukan oleh niat konsumen. Penelitian terdahulu menunjukkan beberapa faktor yang mempengaruhi intention to use. Menurut Pavlou (2003), kepercayaan akan mempengaruhi sikap positif konsumen yang mempengaruhi intention to use. Pada penelitian Kim et al. (2010), dijelaskan bahwa ketika konsumen mendapatkan manfaat yang dirasakan dalam menggunakan e-payment, maka akan memberikan pengaruh yang positif pada niat pengguna untuk menggunakan e-payment tersebut. Kemudian, penelitian Luarn dan Lin (2005) menemukan pengaruh yang positif dari variabel perceived ease of use terhadap variabel intention to use.

Studi ini dilakukan untuk mengkaji apakah trust, perceived ease of use, dan perceived usefulness merupakan prediktor positif intention to use. Hasil yang diperoleh dari penelitian ini diharapkan dapat menjadi informasi terkait dengan faktor-faktor yang merupakan prediktor siginifian variabel intention to use.

\section{Kajian teori}

Penelitian ini mengacu pada teori Unified Theory of Acceptance and Use of Technology (UTAUT) yang dikembangkan oleh Venkatesh et al. (2016) yang menjelaskan adanya hubungan antara penerimaan dan penggunaan teknologi dengan niat pengguna untuk menggunakan produk. Kedua teori tersebut menggambarkan adanya hubungan antara kepercayaan dan penerimaan produk kepada pengguna produk yang menjadi nilai penting bagi perusahaan. Bila pengguna sudah menerima, merasakan manfaat dan percaya kepada produk, maka pengguna tersebut harus dipertahankan oleh perusahaan karena kedepannya akan menguntungkan kedua belah pihak. Pihak perusahaan akan mendapat kepercayaan konsumen dan produknya akan menjadi berguna di masyarakat, sementara pihak pengguna akan mendapat peningkatan kinerja, produktifitas dan efisien waktu.

Lebih lanjut, kedua teori tersebut menjelaskan bahwa bila perusahaan ingin mendapat kepercayaan pengguna produk, maka perusahaan harus memiliki perencanaan dan prediksi rancangan produk yang akan digunakan pengguna tersebut. Upaya sederhana yang perusahaan bisa lakukan yaitu memenuhi keinginan pengguna dalam harapan kinerja, harapan usaha, dan pengaruh sosial. Upaya tersebut memungkinkan adanya pengaruh niat perilaku pengguna untuk menggunakan produk perusahaannya.

\section{Intention to use}

Davis (1989: 334) menjelaskan intention to use sebagai "tendency of consumer behavior to keep using a product provided by the company. The level of use of a product on users can be predicted from the attitude of attention to the product". Intention to use adalah kecenderungan pada perilaku konsumen untuk terus menggunakan produk yang diberikan oleh perusahaan. Tingkat penggunaan produk tersebut dapat diprediksi berdasarkan perhatian dan sikapnya terhadap produk.

Berdasarkan pengertian tersebut, penelitian ini mendefinisikan intention to use sebagai kecenderungan perilaku pengguna untuk menggunakan produk perusahaan dengan tingkat seberapa kuat keinginan menggunakannya tersebut. 


\section{Trust}

Menurut Gefen et al. (2003: 52), "Trust can be defined as a customer's confident beliefs concerning a product's honesty with regards to how they treat their customers and trust often refers to the expectations that one party has that the other party won't behave opportunistically". Kepercayaan dapat didefinisikan sebagai kepercayaan pengguna tentang kejujuran suatu produk yang berhubungan dengan bagaimana perusahaan memperlakukan pengguna dan kepercayaan sering merujuk pada ekspektasi pengguna bahwa perusahaan tidak akan melakukan tindakan oportunistik. Hendro dan Keni (2020) mendefinisikan trust sebagai kepercayaan pelanggan terhadap suatu merek, dimana pelanggan percaya bahwa merek tersebut memiliki kemampuan untuk memenuhi harapan pelanggan.

Berdasarkan definisi di atas, penelitian ini menyimpulkan trust sebagai keyakinan konsumen terhadap kejujuran yang didapati konsumen dari produk perusahaan.

\section{Perceived usefulness}

Davis (1989: 320) menjelaskan perceived usefulness sebagai "the extent to which a person believes that using a particular technology will enhance her/his job performance". Persepsi kemanfaatan adalah sejauh mana seorang pengguna akan percaya bahwa dengan menggunakan suatu teknologi tertentu dapat meningkatkan kinerjanya. Keni (2020) mendefinisikan perceived usefulness sebagai penilaian pelanggan mengenai seberapa teknologi yang akan mereka gunakan akan meningkatkan kualitas hasil pekerjaan dan aktivitas mereka.

Berdasarkan definisi tersebut, penelitian ini mendefinisikan perceived usefulness sebagai persepsi konsumen terhadap manfaat yang dirasakan atas penggunaan produk perusahaan.

\section{Perceived ease of use}

Pada penelitian Monsuwe et al. (2004: 104), perceived ease of use dijelaskan sebagai "perceived ease of use refers to their perceptions regarding the process leading to the final outcome". Persepsi kemudahan mengacu pada persepsi pengguna mengenai proses yang mengarah ke hasil akhir.

Berdasarkan pengertian di atas, penelitian ini menyimpulkan bahwa perceived ease of use adalah persepsi konsumen terhadap kemudahan yang diperoleh atas penggunaan produk perusahaan.

\section{Kaitan antara trust dan intention to use}

Mcknight et al. (2002) melalui penelitiannya menunjukkan bahwa trust terhadap situs web mempengaruhi secara positif terhadap niat untuk menggunakannya, sementara Pavlou (2003) mengatakan bahwa kepercayaan mempengaruhi niat untuk menggunakan produk secara positif dengan mengurangi ketakutan tentang perilaku oportunistik. Penelitian $\mathrm{Gu}$ et al. (2009) menunjukkan bahwa mempercayai produk memungkinkan pengguna untuk melihat nilai yang didapati oleh pengguna dari menggunakan mobile banking yang menyebabkan dorongan niat menggunakan kepada pengguna untuk menggunakannya. Selanjutnya, penelitian Gefen et al. (2003) menjelaskan bahwa tingkat kepercayaan pengguna terhadap intensi untuk menggunakan produk akan dipengaruhi dengan seberapa tinggi niat untuk menggunakan produk tersebut. Berdasarkan argumentasi di atas, hipotesis penelitian (H1) dirumuskan sebagai berikut:

H1: Trust dapat memprediksi secara positif intention to use brand e-payment di Jakarta. 


\section{Kaitan antara perceived usefulness dan intention to use}

Davis (1989) melalui penelitiannya menunjukkan bahwa berbagai manfaat yang akan dirasakan konsumen dapat menghasilkan pengaruh yang positif terhadap intensi untuk menggunakan produk. Hal ini dijelaskan dengan niat pengguna untuk menggunakan produk perusahaan didasarkan pada seberapa besar pengguna membutuhkannya dan seberapa manfaat yang dirasakan dari produk tersebut. Pengguna akan menggunakan produk pada saat pertama kalinya dengan harapan bahwa apa yang sebelumnya tidak bisa dilakukan menjadi bisa dilakukan dan lebih bermanfaat bagi pengguna. Kemudian, Sun et al. (2012) menunjukan bahwa perceived usefulness secara positif dan signifikan dapat mempengaruhi intensi untuk menggunakan $e$ payment. Selanjutnya, Venkatesh dan Morris (2000) juga menunjukkan bahwa manfaat dari produk yang dirasakan oleh pengguna akan berpengaruh terhadap intensi untuk menggunakannya. Selain itu, studi Lee dan Wan (2010) tentang e-ticketing di China menemukan hubungan positif antara variabel perceived usefulness dan niat menggunakan produk. Berdasarkan argumentasi di atas, hipotesis penelitian (H2) dirumuskan sebagai berikut:

H2: Perceived usefulness dapat memprediksi secara positif intention to use brand e-payment di Jakarta.

\section{Kaitan antara perceived ease of use dan intention to use}

Davis et al. (1989) menjelaskan bahwa hasil uji dari hubungan persepsi kemudahaan dan niat untuk menggunakan produk adalah positif. Kemudahan yang diperoleh atas penggunaan suatu produk akan mempengaruhi niat konsumen untuk menggunakan produk tersebut. Sementara itu, studi menemukan bahwa variabel perceived ease of use dapat secara positif mempengaruhi niat menggunakan pembelajaran melalui web (Chiu \& Wang, 2008). Selanjutnya, dalam penelitian Rokhman (2011) tentang e-government di Indonesia, ditemukan bahwa banyak pengguna yang senang menggunakan e-government karena terdapat kemudahaan yang didapat oleh pengguna. Berdasarkan argumentasi di atas, hipotesis penelitian (H3) dirumuskan sebagai berikut:

H3: Perceived ease of use dapat memprediksi secara positif intention to use brand e-payment di Jakarta.

Berdasarkan uraian mengenai hubungan antar variabel di atas, model penelitian yang akan diteliti dalam penelitian ini ditunjukkan pada Gambar 1 sebagai berikut:

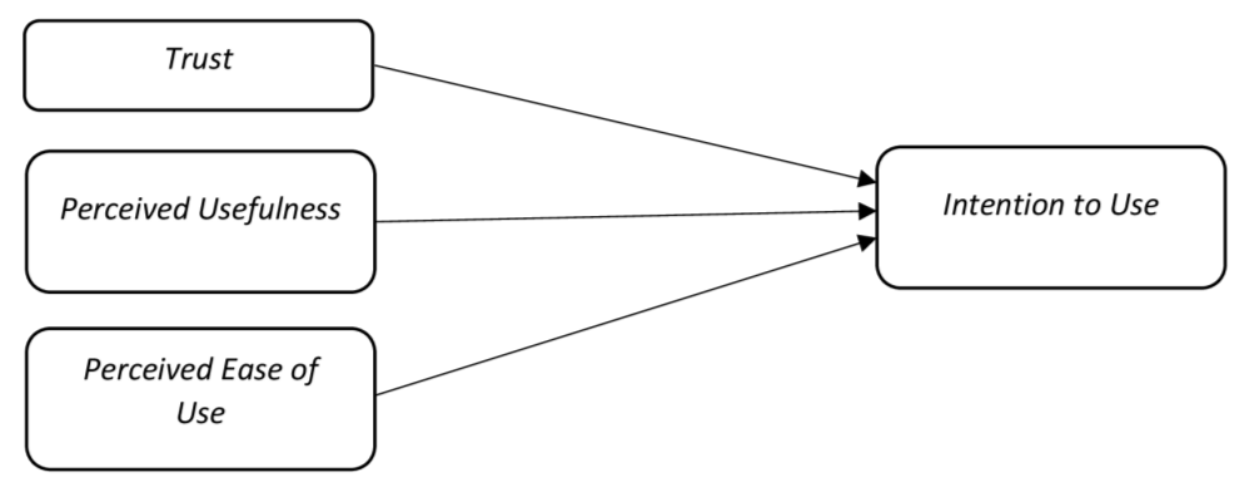

Gambar 1. Model penelitian

\section{METODE PENELITIAN}

Penelitian ini merupakan penelitian deskriptif dengan pendekatan cross-sectional design. Sampel yang digunakan ialah konsumen yang sudah pernah atau sedang memakai aplikasi pembayaran 
e-payment. Pengumpulan sampel dilakukan dengan metode non-probability sampling dengan teknik convenience sampling. Jumlah responden yang dikumpulkan sebanyak 170 responden. Dari 170 responden tersebut, mayoritas responden merupakan pria (51\%), memiliki pendidikan terakhir SMA (83\%), berusia di antara 17-25 tahun (99\%), memiliki pekerjaan sebagai seorang mahasiswa (89\%) dan intensitas menggunakan aplikasi pembayaran e-payment dalam seminggu sebanyak 1 kali seminggu (47\%).

Tabel 1. Indikator pengukuran variabel

\begin{tabular}{ccc} 
Variabel & Item & Sumber \\
\hline Intention to Use & 4 & Kim et al. (2010); Luarn dan Lin (2005) \\
\hline Trust & 4 & Rotchanakitumnuai dan Speece (2009) \\
\hline Perceived Usefulness & 4 & Kim et al. (2010); Luarn dan Lin (2005) \\
\hline Perceived Ease of Use & 5 & Kim et al. (2010); Luarn dan Lin (2005); Ismail (2016) \\
\hline
\end{tabular}

Seluruh variabel diukur dengan skala Likert 5 poin, dengan angka 1 merupakan "Sangat Tidak Setuju" dan angka 5 merupakan "Sangat Setuju". Variabel penelitian diukur dengan indikator yang diadaptasi dari penelitian terdahulu, seperti yang ditunjukkan pada Tabel 1. Pada analisis validitas dan reliabilitas, 17 indikator menghasilkan nilai loading factors lebih tinggi dari 0,7 dan nilai AVE lebih tinggi dari 0,5, sehingga seluruh indikator telah memenuhi kriteria analisis validitas konvergen dan validitas diskriminan yang dianalisis dengan menggunakan FornellLarcker serta cross loadings. Terakhir, pengujian reliabilitas menunjukkan bahwa seluruh variabel memiliki nilai composite realibilty dan Cronbach's alpha lebih tinggi dari 0,6, sehingga menurut Malhotra (2014), seluruh variabel dinyatakan reliabel.

\section{HASIL DAN PEMBAHASAN}

Pada penelitian ini, dilakukan juga pengujian path coefficient yang bertujuan untuk mengetahui keterkaitan antar variabel. Tabel 2 menunjukkan hasil pengujian bootsraping yang terdiri dari path coefficient, $t$-statistics, dan $p$-values.

Tabel 2. Hasil analisis path coefficient

\begin{tabular}{ccccc} 
Hipotesis & Variabel & Path Coefficient & t-statistics & p-values \\
\hline $\mathrm{H}_{1}$ & Trust $\gg$ Intention to Use & 0,271 & 3,307 & 0,001 \\
\hline $\mathrm{H}_{2}$ & Perceived Usefulness $\gg$ Intention to Use & 0,544 & 6,617 & 0,000 \\
\hline $\mathrm{H}_{3}$ & Perceived Ease of Use $»$ Intention to Use & 0,004 & 0,052 & 0,958
\end{tabular}

Berdasarkan nilai path coefficient yang ditampilkan pada Tabel 2, dapat disimpulkan bahwa nilai path coefficient variabel trust terhadap intention to use berarah positif dengan nilai sebesar 0,271; nilai path coefficient perceived usefulness terhadap intention to use berarah positif dengan nilai sebesar 0,544; dan nilai path coefficient perceived ease of use terhadap variabel intention to use memiliki arah positif dengan nilai 0,004. Berdasarkan nilai path coefficient pada Tabel 2, perceived usefulness merupakan prediktor terbesar untuk intention to use, yaitu sebesar 0,544.

Hasil pengujian hipotesis (H1) menunjukan bahwa trust terbukti dapat memprediksi secara positif terhadap intention to use e-payment di Jakarta. Hasil tersebut konsisten dengan studi Mcknight et al. (2002), Pavlou (2003), Gefen et al. (2003), dan Gu et al. (2009) yang menemukan bahwa trust secara positif dapat meningkatkan atau mendorong intention to use penggunanya. Adanya rasa kepercayaan dari pengguna terhadap suatu aplikasi atau e-payment dapat meningkatkan niat untuk menggunakan pada suatu produk tersebut. Kemudian, tingkat 
kepercayaan pengguna untuk menggunakan produk dipengaruhi dengan seberapa tinggi niat untuk menggunakan produk tersebut.

Selanjutnya, hasil pengujian hipotesis (H2) menunjukkan bahwa perceived usefulness terhadap intention to use pengguna e-payment di Jakarta juga terbukti dapat memprediksi secara positif. Karena hasil pengujian hipotesis tersebut tidak ditolak, maka dapat disimpulkan bahwa penelitian ini konsisten dengan pendapat Davis et al. (1989), Venkatesh dan Morris (2000), Sun et al. (2012), dan Lee dan Wan (2010). Hasil tersebut membuktikan bahwa persepsi kemanfaatan berperan penting bagi memunculkan atau meningkatkan niat menggunakan e-payment kepada penggunanya. Hal ini dijelaskan dengan niat pengguna untuk menggunakan e-payment didasarkan pada seberapa besar pengguna membutuhkannya dan seberapa manfaat yang dirasakan dari e-payment tersebut. Pengguna akan menggunakan e-payment pada saat pertama kalinya dengan harapan apa yang tidak bisa dilakukan menjadi bisa dilakukan dan lebih bermanfaat bagi pengguna.

Hasil pengujian hipotesis (H3) menunjukkan bahwa variabel perceived ease of use terhadap intention to use tidak dapat memprediksi secara positif, sehingga hipotesis $(\mathrm{H} 3)$ ditolak dan penelitian ini tidak konsisten dengan Davis et al. (1989), Chiu dan Wang (2008), dan Rokhman (2011). Adanya persepsi kemudahaan terhadap e-payment tidak dapat meningkatkan intention to use pengguna e-payment, sehingga kemudahaan dalam menggunakan e-payment tidak dapat menjamin bahwa pengguna akan memiliki niat yang lebih tinggi untuk menggunakan e-payment tersebut.

\section{KESIMPULAN DAN SARAN}

Penelitian ini menyimpulkan bahwa trust dan perceived usefulness dapat memprediksi secara positif intention to use e-payment di Jakarta secara signifikan, sedangkan perceived ease of use tidak dapat secara positif memprediksi intention to use pengguna e-payment di Jakarta.

Penelitian ini menyarankan perusahaan e-payment untuk terus meningkatkan layanannya kepada dalam rangka menumbuhkan rasa kepercayaan terhadap aplikasi e-payment itu sendiri. Tingkat keamanan dan penyimpanan data informasi pribadi yang aman menjadi keunggulan e-payment yang dapat meningkatkan kepercayaan pengguna kepada aplikasi e-payment. Selain itu, perusahaan e-payment perlu untuk terus membangun dan meningkatkan perceived usefulness antara pengguna dengan aplikasi e-payment untuk mempertahankan intention to use aplikasi $e$ payment. Dengan adanya kemanfaatan yang baik dipahami oleh pengguna, maka akan membantu memberikan rasa efektivitas dan efisiensi dalam kebutuhan sehari-hari serta peningkatan kinerja pengguna e-payment.

Penelitian ini menyarankan penelitian selanjutnya untuk dilakukan di wilayah dengan jangkauan pengumpulan sampel dan wilayah yang lebih luas, sehingga dapat melengkapi dan memperkuat hasil penelitian terdahulu. Penelitian ini juga menyarankan untuk menambah variabel yang belum dikaji dalam penelitian ini, sehingga variabel tersebut diharapkan dapat secara lebih akurat mengukur dan menghasilkan lebih banyak kontribusi dalam memprediksi intention to use e-payment di Jakarta. 


\section{Ucapan Terima Kasih}

Penelitian ini mengucapkan terima kasih banyak kepada berbagai pihak terkait yang sudah mendukung, memotivasi dan berpartisipasi dalam pelaksanaan proses penelitian ini baik dari tahap awal sampai tahap akhir.

\section{REFERENSI}

Chiu, C. M., \& Wang, E. T. G. (2008). Understanding Web-based learning continuance intention: The role of subjective task value. Information and Management, 45(3), 194-201. https://doi.org/10.1016/j.im.2008.02.003

Davis, F. D. (1989). Perceived usefulness, perceived ease of use, and user acceptance of information technology. MIS Quarterly: Management Information Systems, 13(3), 319-339. https://doi.org/10.2307/249008

Davis, F. D., Bagozzi, R. P., \& Warshaw, P. R. (1989). User Acceptance of Computer Technology: A Comparison of Two Theoretical Models. Management Science, 35(8), 9821003. https://doi.org/10.1287/mnsc.35.8.982

Gefen, D., Karahanna, E., \& Straub, D. W. (2003). Trust and TAM in online shopping: an integrated model. MIS Quarterly, 27(1), 51-90. https://doi.org/10.2307/30036519

Gu, J. C., Lee, S. C., \& Suh, Y. H. (2009). Determinants of behavioral intention to mobile banking. Expert Systems with Applications, 36(9), 11605-11616. https://doi.org/10.1016/j.eswa.2009.03.024

Hendro, \& Keni. (2020). eWOM dan Trust sebagai Prediktor terhadap Purchase Intention: Brand Image sebagai Variabel Mediasi. Jurnal Komunikasi, 12(2), 298-310. https://doi.org/10.24912/jk.v12i2.7760

Ismail, H. A. (2016). Intention to Use Smartphone through Perceived Compatibility, Perceived Usefulness, and Perceived Ease of Use. Jurnal Dinamika Manajemen, 7(1), 1-10. https://doi.org/10.15294/jdm.v7i1.5748

Keni, K. (2020). How Perceived Usefulness and Perceived Ease of Use Affecting Intent to Repurchase? Jurnal Manajemen, 24(3), 481-496. http://dx.doi.org/10.24912/jm.v24i3.680

Kim, C., Mirusmonov, M., \& Lee, I. (2010). An empirical examination of factors influencing the intention to use mobile payment. Computers in Human Behavior, 26(3), 310-322. https://doi.org/10.1016/j.chb.2009.10.013

Lee, C. B. P., \& Wan, G. (2010). Including Subjective Norm and Technology Trust in the Technology Acceptance Model: A Case of E-Ticketing in China. Data Base for Advances in Information Systems, 41(4), 40-51. https://doi.org/10.1145/1899639.1899642

Luarn, P., \& Lin, H. H. (2005). Toward an understanding of the behavioral intention to use mobile banking. Computers in Human Behavior, 21(6), 873-891. https://doi.org/10.1016/j.chb.2004.03.003

Malhotra, N. K. (2014). Basic Marketing Research. Pearson.

Mcknight, D. H., Choudhury, V., \& Kacmar, C. (2002). Developing And Validating Trust Measure for E-Commerce: An Integrative Typology. Information Systems Research, 13(3), 334-359. https://doi.org/10.1287/isre.13.3.334.81

Monsuwe, T. P., Dellaert, B. G., \& De Ruyter, K. (2004). What drives consumers to shop online? A literature review. International Journal of Service Industry Management, 15(1), 102-121. https://doi.org/10.1108/09564230410523358

Pavlou, P. A. (2003). Consumer acceptance of electronic commerce: Integrating trust and risk with the technology acceptance model. International Journal of Electronic Commerce, 7(3), 
101-134. https://doi.org/10.1080/10864415.2003.11044275

Rokhman, A. (2011). E-Government Adoption in Developing Countries; the Case of Indonesia. Journal of Emerging Trends in Computing and Information Sciences, 2(5), 228-236.

Rotchanakitumnuai, S., \& Speece, M. (2009). Modeling electronic service acceptance of an e-securities trading system. Industrial Management \& Data Systems, 109(8), 1069-1084. https://doi.org/10.1108/02635570910991300

Sun, S., Goh, T., Fam, K. S., \& Xue, Y. (2012). The influence of religion on Islamic mobile phone banking services adoption. Journal of Islamic Marketing, 3(1), 81-98. https://doi.org/10.1108/17590831211206617

Venkatesh, V., \& Morris, M. G. (2000). Why Don't Men Ever Stop to Ask for Directions? Gender, Social Influence, and Their Role in Technology Acceptance and Usage Behavior. Management Information Systems Research Center, 24(1), 115-139. https://doi.org/10.2307/3250981

Venkatesh, V., Thong, J. Y. L., \& Xu, X. (2016). Unified theory of acceptance and use of technology: A synthesis and the road ahead. Journal of the Association for Information Systems, 17(5), 328-376. https://doi.org/10.17705/1jais.00428 